\title{
Hemiptera species determined in almond orchards in Mugla and Manisa provinces of Turkey and population fluctuation of Monosteira unicostata (Hemiptera: Tingidae)*
}

\author{
Mehmet Fatih TOLGA ${ }^{1}$, Zeynep YOLDAŞ ${ }^{2}$ \\ ${ }^{1}$ Directorate of Plant Protection Research Institute, Izmir \\ ${ }^{2}$ Department of Plant Protection, Faculty of Agriculture, Ege University, Izmir
}

*The study was oral presented at the 4th Internatıonal Agriculture Congress 05 - 08 July 2018, Nevşehir, Turkey.

Alınış tarihi: 28 Şubat 2019, Kabul tarihi: 2 Ekim 2019

Sorumlu yazar: Mehmet Fatih TOLGA, e-posta: mfatih.tolga@tarimorman.gov.tr

\begin{abstract}
This study was carried out in the localities of Datça, Fethiye, Seydikemer (Mugla) and Akhisar, Kula (Manisa) where almond plantations are common in Aegean region from 2014 to 2016. During this study, 63 insect species belonging to 18 families from Hemiptera order were found. Among these insects 15 species feed in almond trees. For the first time, Typhlocyba rosae and Zygina discolor were identified to feed in almond trees in Turkey in this study. $T$. rosae and $\mathrm{Z}$. discolour feed on and under the leaves this situation lead to leaves turn into whitish. It was concluded that Monosteira unicostata, which has the highest population density among species.
\end{abstract}

Key words: Almond, Almond pests, Hemiptera, Monosteira unicostata

Türkiye'nin Muğla ve Manisa illerinde badem bahçelerinde tespit edilen Hemiptera türleri ve Monosteira unicostata (Hemiptera: Tingidae)'nın popülasyon değişimi

$\ddot{0} \mathbf{z}$

$\mathrm{Bu}$ çalışma, 2014-2016 yılları arasında Ege Bölgesi'nde badem yetiştiriciliğinin yaygın olduğu Datça, Fethiye, Seydikemer (Muğla) ve Akhisar, Kula (Manisa) ilçelerinde yapılmıştır. Bu çalışma sırasında Hemiptera takımına bağlı 18 familyaya ait 63 böcek türü bulunmuştur. $\mathrm{Bu}$ böcekler arasında 15 tür badem ağaçlarında beslendiği saptanmıştır. Typhlocyba rosae ve Zygina discolor türlerinin
Türkiye'de badem ağaçlarında beslenmeleri ilk kez bu çalışma ile tespit edilmiştir. Typhlocyba rosae ve

Z. discolor yaprakların üzerinde ve altında renk solması yapar ve bu durum yaprakların beyazımsı hale gelmesine neden olur. Türler arasında en yüksek popülasyona sahip olan türün Monosteira unicostata olduğu sonucuna varılmıștır.

Anahtar kelimeler: Badem, Badem zararlıları, Hemiptera, Monosteira unicostata

\section{Introduction}

The suitability of the ecological conditions of Turkey, the abundance of land and demands in externalinternal makets are encouraging the rapid increase of almond production. Especially in recent years, the presence of almond orchards increases significantly as a result of almond planting for the forestation of large areas that have lost its forest nature. According to the data of Turkish Statistical Institute (Tüik, 2018), at the most almonds produced provinces are Adiyaman (48714 da), Sanliurfa (33842 da), Manisa (33505 da) and Mugla (20084 da). The survey was carried out in almond orchards in Aegean region almond areas, Manisa and Mugla provinces. There are many records about Hemiptera fauna in Turkey. However, there is no data on the Hemiptera order in almond production areas in the Aegean region. In this study, the Hemiptera species found in almond trees were determined and the species fed with almond trees were tried to be determined. Data on the potential damage of the species fed with almond trees were obtained. 


\section{Materials And Methods}

This study was conducted between 2014 and 2016 in Manisa province Akhisar, Kula and Mugla province Datca, Fethiye, Seydikemer districts on almond orchards. The methods used to collect Hemiptera samples are visual sampling, beating randomly choosen tree branches of different sides of each orchard. According to these methods, the species fed by different parts of the almond trees were identified and recorded.

The population fluctuation of the Monosteira unicostata was monitored by weekly sampling from January to November. The sampling method was frappage method (hitting the 25 trees, 4 strokes per tree, and collecting the falling individuals on a $40 * 40$ $\mathrm{cm}$ sized cloth). In order to determine the damage rate, 100 twigs were collected from each orchard, and twigs with discoloration leaves caused by the pest were recorded as damaged.

\section{Results}

\section{Hemiptera Species}

Results of the study, 63 insect species belonging to 18 families from Hemiptera order were found. Among these insects 15 species fed from different part of almond trees.

\section{Achilidae}

Cixidia parnassia (Stal, 1859)

Manisa: Akhisar, 31.V.2016, (1); Muğla: Fethiye, 29.IV.2015, (1); Seydikemer, 29.IV.2015, (2); 11.V.2016, (3). Totally 7 specimens.

\section{Anthocoridae}

Anthocoris nemorum (Linnaeus, 1761)

Manisa: Akhisar, 05.VI.2015, (2); 09.III.2015, (1); Muğla: Datça, 7.V.2014, (1); 20.V.15, (3); 30.VII.2016, (3); Fethiye, 29.IV.2015 (1). Totally 11 specimens.

\section{Aphrophoridae}

Lepyronia coleoptrata (Linnaeus, 1758)

Manisa: Kula, 12.VI.2015, (1). Totally 1specimens

Philaenus spumarius (Linnaeus, 1758)

Manisa: Akhisar, 01.V.2014, (1); Muğla: Datça, 20.IV.2015, (2); 30.IV.2015, (1); 15.I.2016, (1). Totally 5 specimens.

\section{Aphididae}

Brachycaudus amygdalinus (Schouteden, 1905)

Manisa: Akhisar, 16.IV.2014, (80); Kula, 30.V.2014, (120); Muğla: Datça, 01.IV.2014, (10); Fethiye,
22.IV.2014, (50); 19.III.15, (50); Seydikemer, 22.IV.2014, (25). Totally 335 specimens.

Hyalopterus pruni (Geoffroy, 1762)

Manisa: Akhisar, 16.IV.2014, (60); Kula, 25.IV.2014, (65); Muğla: Datça, 28.III.2014, (25); Fethiye, 16.IV.2014, (130); Seydikemer, 16.IV.2014, (20); 22.VII.2015, (30). Totally 300 specimens.

Brachycaudus cardui (Linnaeus, 1758)

Manisa: Akhisar, 04.IV.2014, (145); Kula, 25.III.2014, (65); Muğla: Datça, 01.IV.2014, (10); Fethiye, 19.III.2014, (15); Seydikemer, 06.V.2014, (20). Totally 255 specimens.

Rhopalosiphum nymphaeae (Linnaeus,1761)

Manisa: Akhisar, 16.IV.2014 (25); Kula, 25.IV.2014, (40); Muğla: Datça, 28.III.2014, (10); Fethiye, 08.IV.2014, (10); Seydikemer, 06.V.2014, (10). Totally 95 specimens.

\section{Cicadellidae}

Aphrodes bicinctus (Schrank, 1776)

Manisa: Akhisar, 05.VI.2015, (3). Totally 3 specimens.

Asymmetrasca decedens (Paoli, 1932)

Manisa: Akhisar, 26.III.2014, (9); 04.IV.2014, (4); 16.IV.2014, (25); 21.V.2014, (124); 03.VII.2014, (32); 20.III.2015, (35); 12.VI.2015, (15); $10 . I I I .2016$ (16); 18.VIII.2016, (2); Kula, 25.IV.2014, (40); 29.V.2014, (1); 09.III.2015, (15); 12.IV.2016, (5); 14.VI.2016 (42); Muğla: Datça, 01.VII.2014, (2); 03.IV.2015, (13); 19.II.2016, (2); 29.IV.2016, (2); Fethiye, 08.IV.2014, (10); Seydikemer, 06.V.2014, (10); 17.VI.2014, (3); 20.VII.2014 (8). Totally 415 specimens.

Typhlocyba rosae Jensen-Haarup, 1920

Manisa: Akhisar, 06.III.2014, (1); 04.IV.2014, (4); 21.V.2014, (105); 19.VI.2015, (20); 20.III.2015, (20); 12.VI.2015, (15); 10.III.2016, (6); Kula, 25.III.2014, (10); 15.VII.2016, (25); Muğla: Datça, 09.VI.2015, (12); 10.VII.2015, (25); 29.IV.2016, (2); Fethiye, 12.III.2015, (5); 19.III.2015, (2); Seydikemer, 17.VI.2014, (3). Totally 255 specimens.

Zyginidia discolor Horvath, 1897

Manisa: Akhisar, 26.III.2014, (8); 09.VI.2014, (28); 19.VI.2015, (7); 30.III.2015, (5); 19.VI.2015, (7); Kula, 05.VI.2015, (8); 10.VII.2015, (5); 19.II.2016, (6); Muğla: Datça, 13.III.2015, (10); 03.IV.2015, (20); 17.IV.2015, (2); 16.IV.2015, (6). Totally 112 specimens. 
Eupelix cuspidata (Fabricius, 1779)

Muğla: Fethiye, 29.IV.2015, (1). Totally 1 specimens. Euscelis lineolatus Brulle, 1832

Manisa: Akhisar, 10.VII.2015, (1). Totally 1 specimens.

Hardya anatolica Zachvatkin, 1946

Manisa: Akhisar, 31.V.2016, (2). Totally 2 specimens.

Megophtphalmus scabripennis Edwards, 1915

Manisa: Akhisar, 20.III.2015, (3); 07.V.2015, (3); Muğla: Datça, 01.IV.2014, (1); 30.IV.2014, (3); 07.VIII.2014, (2); 21.IV.2015, (6). Totally 18 specimens.

Neoaliturus fenestratus (Herrich-Schaeffer, 1834)

Manisa: Akhisar, 22.V.2015, (1); Muğla: Seydikemer, 02.VII.2014, (1). Totally 2 specimens.

Tremulicerus mesopyrrhus Kirschbaum, 1868

Manisa: Akhisar, 20.III.2015, (4). Totally 4 specimens.

\section{Cicadidae}

Cicada mordoganensis Boulard, 1979

Muğla: Datça, 21.VII.2014, (37); Fethiye, 01.VIII.2016, (12); Seydikemer, 01.VIII.2016, (9). Totally 58 specimens.

Lyristes plebejus (Scopoli, 1763)

Muğla: Datça, 23.VIII.2016, (7); Fethiye, 22.VIII.2016;

(4); Seydikemer, 22.VIII.2016, (5). Totally 16 specimens.

\section{Cixiidae}

Eumecurus bourouensis (Linnavuori, 1965)

Manisa: Akhisar, 10.III.2016, (2); Kula, 18.IX.2015, (1). Totally 3 specimens.

Pentastiridius leporinus (Linnaeus, 1761)

Muğla: Datça, 01.VII.2014, (3). Totally 3 specimens.

Pentastira majör Kirschbaum, 1868

Manisa: Akhisar, 03.VII.2015, (1); 10.VII.2015, (2); 15.VII.2016, (4); Kula, 15.VII.2016, (1); Muğla: Datça, 01.VII.2014, (5); 14.VII.2016, (2); Fethiye, 11.V.2016, (3). Totally 18 specimens.

Reptalus melanochaetus (Fieber, 1876)

Manisa: Akhisar, 03.VII.2015, (3); Kula, 23.VI.2014, (2); 30.VI.2015, (1); 26.VI.2014, (2); Muğla: Seydikemer, (2). Totally 10 specimens.

\section{Coreidae}

Coreus marginatus (Linnaeus, 1758)
Manisa: Akhisar, 03.VII.2015, (1); Muğla: Datça, 02.VIII.2016, (1). Totally 2 specimens.

Enoplops disciger (Kolenati, 1845)

Muğla: Datça, 01.IV.2016, (1); Seydikemer, 29.IV.2015, (1); 02.VI.2016, (1). Totally 3 specimens.

Centrocoris variegatus Kolenati, 1845

Muğla: Datça, 20.V.2015, (2). Totally 2 specimens.

Gonocerus acuteangulatus (Goeze, 1778)

Manisa: Akhisar, 18.IX.2015, (1); Muğla: Datça, 15.I.2016, (2); 29.IV.2016, (2). Totally 5 specimens.

Camptopus lateralis (Germar, 1817)

Manisa: Akhisar, 15.VII.2016, (3); Kula, 25.III.2014, (2); 02.X.2015, (1); 25.III.2014, (2). Totally 8 specimens.

\section{Cydnidae}

Sehirus morio (Linnaeus, 1761)

Manisa: Akhisar, 04.IV.2014, (1); 12.VI.2015, (1); Muğla: Datça, 17.IV.2015, (1); 12.V.2015, (1). Totally 4 specimens.

\section{Diaspididae}

Lepidosaphes ulmi (Linnaeus, 1758)

Muğla: Datça, 07.XII.2016, (20). Totally 20 specimens.

Parlatoria oleae (Colvee, 1880)

Manisa: Akhisar, 21.III.2014, (176); 20.XII.2016, (155). Totally 331 specimens.

\section{Dictyopharidae}

Dictyophara europaea (Linnaeus, 1767)

Manisa: Kula, 25.VI.2014, (2). Totally 2 specimens.

\section{Issidae}

Agalmatium bilobum (Fieber, 1877)

Manisa: Akhisar, 02.II.2014, (35); 21.V.2014, (42); 23.VI.2014, (3); 03.VII.2015, (21); 31.V.2016, (3); Kula, 31.V.2016, (3); Muğla: Datça, 14.II.2014, (45); 07.V.2014, (6); 12.V.2015, (5); 12.V.2016, (19); Fethiye, 19.III.2014, (15); 27.V.2014, (32); 18.VI.2015, (8). Totally 237 specimens.

\section{Lygaeidae}

Corizus hyoscyami (Linnaeus, 1758)

Manisa: Akhisar, 20.III.2015, (2); 10.III.2016, (3); Kula, 25.III.2014, (2); 30.VI.2015, (1); Muğla: Datça, 07.V.2014, (4); 03.IV.2015, (3); Fethiye, 22.IV.2014, (1); Seydikemer, 08.IV.2014, (1); 16.IV.2015, (1). Totally 18 specimens.

Liorhyssus hyalinus (Fabricius, 1794) 
Muğla Datça, 21.IV.2014, (4); 14.X.2015, (2); Seydikemer, 30.IV.2015, (2). Totally 8 specimens.

Oxycarenus hyalinipennis (A. Costa, 1843)

Muğla: Datça, 21.IV.2014, (7); 23.VIII.2016, (9); Seydikemer, 13.X.2015, (2); Manisa: Kula, 10.VII.2015, (2). Totally 20 specimens.

Oxycarenus pallens (Herrich-Schäffer, 1850)

Manisa: Kula, 18.IX.2015, (2); 02.X.2015, (3); Muğla: Datça, 23.VIII.2016, (2); Fethiye, 30.VI.2015, (3); 02.VI.2016, (1). Totally 11 specimens.

Nysius graminicola (Kolenati, 1845)

Manisa: Akhisar, 04.VIII.2014, (1); 07.VIII.2015, (1); Kula, 18.IX.2015, (1); Muğla: Datça, 23.VIII.2014, (1); 20.V.2015, (2); Seydikemer, 30.IV.2015, (1); 13.X.2015, (1). Totally 8 specimens.

Nysius cymoides (Spinola, 1837)

Manisa: Akhisar, 09.VI.2014, (2); Kula, 09.VI.2014, (1); 30.III.2015, (1); 12.VI.2015, (1); Muğla: Datça, 18.III.2014, (3); 01.VII.2014, (1); 14.X.2015, (3); Seydikemer, 13.X.2015, (1). Totally 13 specimens.

Metopoplax origani (Kolenati, 1845)

Manisa: Akhisar, 04.VIII.2014, (2); 11.V.2015, (1); Kula, 13.V.2015, (1); Muğla: Datça, 12.V.2015, (1). Totally 5 specimens.

Macroplax fasciata (Herrich-Schäffer, 1835)

Manisa: Akhisar, 05.VI.2015, (1); Muğla: Datça, 20.V.2015, (1); 17.VI.2015, (16); 01.VII.2015, (1); 16.VI.2016, (3); Seydikemer, 29.IV.2015, (2). Totally 23 specimens.

Geocoris erythrocephalus (Lepeletier \& Serville, 1825)

Manisa: Akhisar, 07.VIII.2015, (3); Kula, 22.VIII.2014, (1); Muğla: Datça, 12.V.2015, (1). Totally 5 specimens.

Lygaeus equestris (Linnaeus, 1758)

Manisa: Akhisar, 26.III.2014, (1); 07.V.2015, (2); 14.VI.2016, (1); Kula, 25.III.2014, (2); 22.IV.2014, (1); 07.V.2015, (1); Muğla: Datça, 30.VII.2015, (1); 15.I.2016, (2); Fethiye, 08.IV.2014, (2); 14.III.2016, (1); Seydikemer, 08.IV.2014, (6); 22.IV.2014, (2); 16.IV.2015, (1). Totally 23 specimens.

\section{Miridae}

Adelphocoris lineolatus (Goeze, 1778)

Manisa: Akhisar, 11.V.2015, (8); Muğla: Datça, 01.IV.2014, (3); 27.III.2015, (1). Totally 12 specimens.

Deraeocoris rutilus (Herrich-Schäffer, 1838)
Manisa: Akhisar, 23.VI.2014, (4); 12.VI.2015, (2); Kula, 25.VI.2014, (3); Muğla: Seydikemer, 30.VI.2015, (2). Totally 11 specimens.

Deraeocoris schach (Fabricius, 1781)

Manisa: Akhisar, 30.IV.2014, (3); Muğla: Datça, 07.V.2014, (1); Fethiye, 19.III.2014 (1). Totally 5 specimens.

Calocoris quadripunctatus (Villers, 1789)

Manisa: Akhisar, 20.III.2015, (2); Kula, 25.IV.2014, (1); Muğla: Datça, 01.IV.2014, (2); 27.III.2015, (3); 21.IV.2015, (2); 12.V.2016, (2); Fethiye, 14.III.2016, (1); Seydikemer, 28.IV.2016, (1). Totally 14 specimens.

Brachynotocoris puncticornis Reuter, 1880

Muğla: Datça, 23.V.2014, (4); 20.V.2015, (4); 09.VI.2015, (2); 17.VI.2015, (2); 12.V.2016, (1). Totally 13 specimens.

Plagiognathus bipunctatus Reuter, 1883

Muğla: Datça, 28.V.2014, (1); 21.IV.2015, (1); 09.VI.2015, (2). Totally 4 specimens.

Agnocoris rubicundus (Fallen, 1807)

Manisa: Akhisar, 07.V.2015, (5); Kula, 12.V.2014, (4); Muğla: Datça, 20.V.2015, (3). Totally 12 specimens.

\section{Pentatomidae}

Mustha spinosula (Lefèbvre, 1831)

Manisa: Akhisar, 23.VI.2014, (2); 05.VI.2015, (2); 12.VI.2015, (1); 03.VII.2015, (3); 17.V.2016, (7); 27.VI.2016, (6); 18.VIII.2016, (15); Kula: 25.VI.2014, (4); 10.VII.2015, (2); Muğla: Datça, 29.VIII.2014, (2); Fethiye, 02.VII.2014, (2); Seydikemer, 02.VII.2014, (4); 30.VI.2015 (5). Totally 55 specimens.

Rhaphigaster nebulosa (Poda, 1761)

Manisa: Akhisar, 10.III.2016, (3); Kula, 19.VI.2015, (2); Kula, 08.VIII.2014, (1); 15.VII.2016, (1); Muğla: Datça, 21.VII.2014, (1); 07.VIII.2014, (4); 01.VII.2015, (2); 20.VIII.2015, (5), 15.I.2016, (4); 03.II.2016, (2); 19.II.2016, (1); 15.III.2016, (2); 01.IV.2016, (1). Totally 29 specimens.

Dolycoris baccarum (Linnaeus, 1758)

Manisa: Akhisar, 25.III.2014, (1); 10.III.2016, (2); Kula, 25.III.2014, (1); 20.IV.2015, (1); 07.VIII.2015, (2); Muğla: Datça, 20.V.2015, (1); Fethiye, 16.IV.2015, (1); Seydikemer, 13.X.2015, (1). Totally 10 specimens.

Eurydema ventralis Kolenati, 1846

Manisa: Akhisar, 10.III.2016, (1); 15.VII.2016, (1). Totally 2 specimens. 
Piezodorus lituratus (Fabricius, 1794)

Manisa: Akhisar, 14.III.2014, (12); 01.V.2014, (5); 15.IV.2015, (8); 31.V.2016, (18), Kula, 25.III.2014, (7); 02.X.2015, (1); Muğla: Datça, 14.III.2014, (9); 13.V.2015, (6); 01.VII.2016, (12); Fethiye, 31.III.2016, (16). Totally 94 specimens.

Codophila varia (Fabricius, 1787)

Manisa: Akhisar, 03.VII.2015, (3); 31.V.2016, (1); 27.VI.2016, (2); 15.VII.2016, (1); Kula, 25.III.2014, (1); 26.VI.2014, (1); Muğla: Datça, 13.VIII.2014, (3); 20.V.2015, (4). Totally 16 specimens.

Graphosoma semipunctatum (Fabricius, 1775)

Manisa: Akhisar, 12.V.2014, (2). Totally 2 specimens.

\section{Rhopalidae}

Rhopalus rufus Schilling, 1829

Muğla: Datça, 01.IV.2014, (1); 20.V.2015, (1). Totally 2 specimens.

Stictopleurus abutilon (Rossi, 1790)

Manisa: Kula, 10.VII.2015, (1); Muğla: Datça, 14.VIII.2014, (1); Fethiye, 22.VIII.2016, (1). Totally 3 specimens.

\section{Tettigometridae}

Tettigometra leucophaea (Preyssler 1792)

Manisa: Akhisar, 09.VI.2014, (1); 19.VI.2015, (2); Muğla: Datça, 12.V.2015, (1); Seydikemer, 13.X.2015, (1). Totally 5 specimens.

\section{Tingidae}

Physatocheila municeps Horvath, 1903

Manisa: Akhisar, 04.IV.2014, (12); 19.VI.2015, (1); 03.VII.2015, (5); 07.VIII.2015, (1). Totally 19 specimens.

\section{Population fluctuation of the Monosteira unicostata}

Monosteira unicostata was identified in Datca, Seydikemer and Akhisar districts between 20142016, in which the study was conducted. In Seydikemer district, only 5 adult individuals were found in one orchard and no damage was observed. Akhisar district was found only in one orchard in 2015, and 70\% damage was detected. However, in the same orchard 1\% damage was detected in 2016 and the population did not increase. M. unicostata was not found in Kula and Fethiye districts. Therefore, population changes studies were conducted only in Datça district. Pest was found in all the almond orchards in Datça. Pests can be seen in almost all regions in Turkey (Lodos, 1982; Önder et al., 2006). Once eggs hatch, nymphs passing through five instars after nymphs stage insect reach the adult stage (Babmorad et al., 2004). This pest appear in April on almond trees in the Aegean Region (Figure 1, Figure 2, Figure 3). In these months daytime, the adults are feeding under the leaves, and in the evening they are usually stored in groups in the lower parts of the tree, hiding in cracks or around new shoots. Overwintering females begin to lay eggs 10-15 days after emergence. From May, overwintered adults mate and female starts insert their eggs. They lay their eggs in the parenchyma tissue, especially near or in the midrip under the leaf. Babmorad et al. (2004), reporded this pest lay their eggs under the leaves. It was seen that the egg is insested in leaf tissue with only the operculum. $M$. unicostata carries out all biological activities such as feeding, mating, egg laying only under the leaf. Although the population density in Datça was very high and caused $100 \%$ damage, it was not seen that individuals were fed uper surface the leaf or left any egg. Optimum development temperature is $16-39{ }^{\circ} \mathrm{C}$ (Sánchez-Ramos et al., 2015). After October, they begin to hide for overwinter.

By dipping the stylet into the leaf and sucking the plant's sap, it consumes chlorophyll and causes yellowish white spots. In the case of high population, it was determined that the leaves were completely yellowed or whitened and causing defoliation of trees. As a result of the defoliation of trees, the trees continue to try develop and try to create leaves again to be able to photosynthesis. In this case, the next year's fruit buds decrease thus resulting in a yield decrease. In addition, almonds harvest become very difficult for people who perform harvest due to the flapping or shaking of branches. During the flapping of the branches, the individual of the pest falls on the employee who performs the harvest and insects spreads all over the body, making uncomfortable.

Gomez-Menor (1950), and Mustafa et al. (2014), reported that the pest is harmful by absorbing plant sap and causing trees to weaken.

Lodos (1982), and Maral et al., (2013) stated that the nymph and adult stages of the pest absorb plant sap under the leaf, causes defoliation and nymphs are living in groups. 


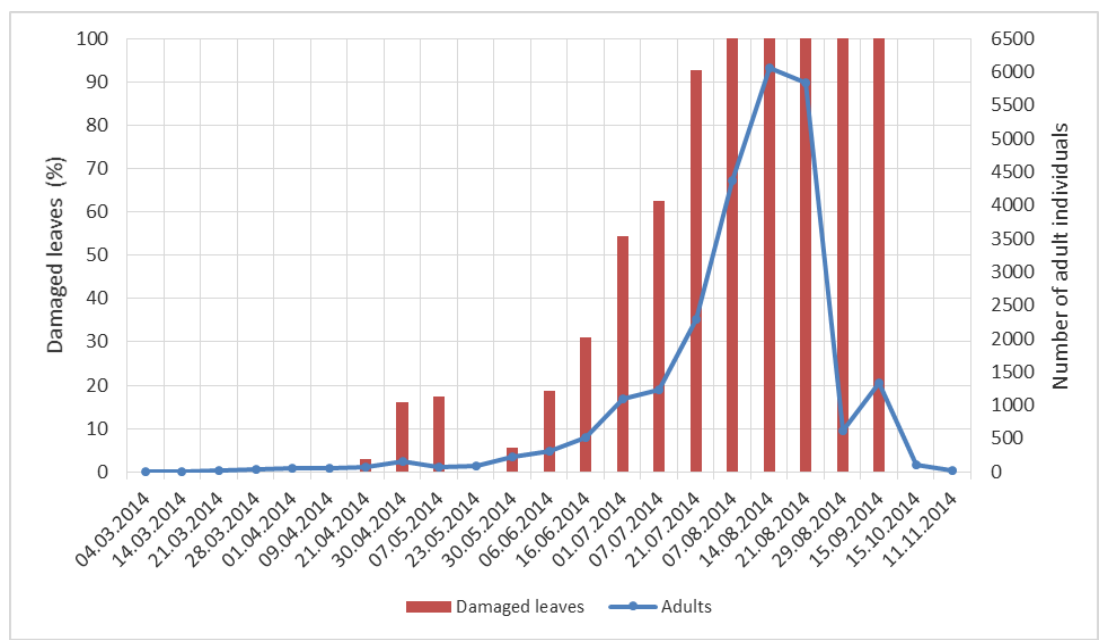

Figure 1. Population fluctuation and damage rates of the Monosteira unicostata (Mulsant \& Rey) in Datça in 2014.

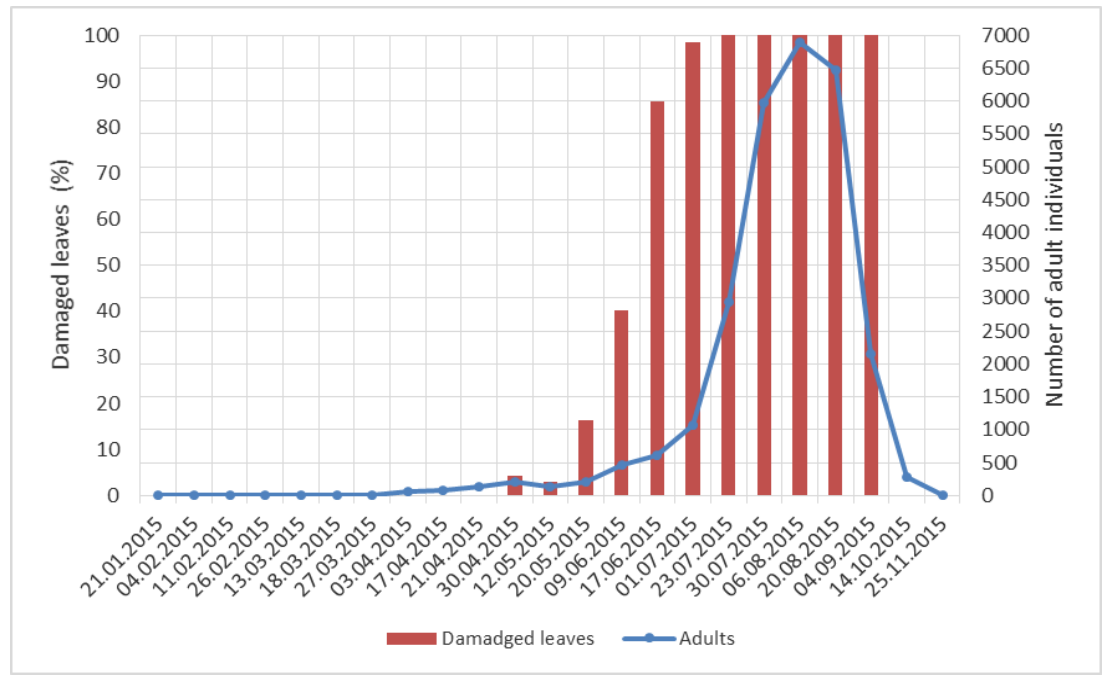

Figure 2. Population fluctuation and damage rates of the Monosteira unicostata (Mulsant \& Rey) in Datça in 2015.

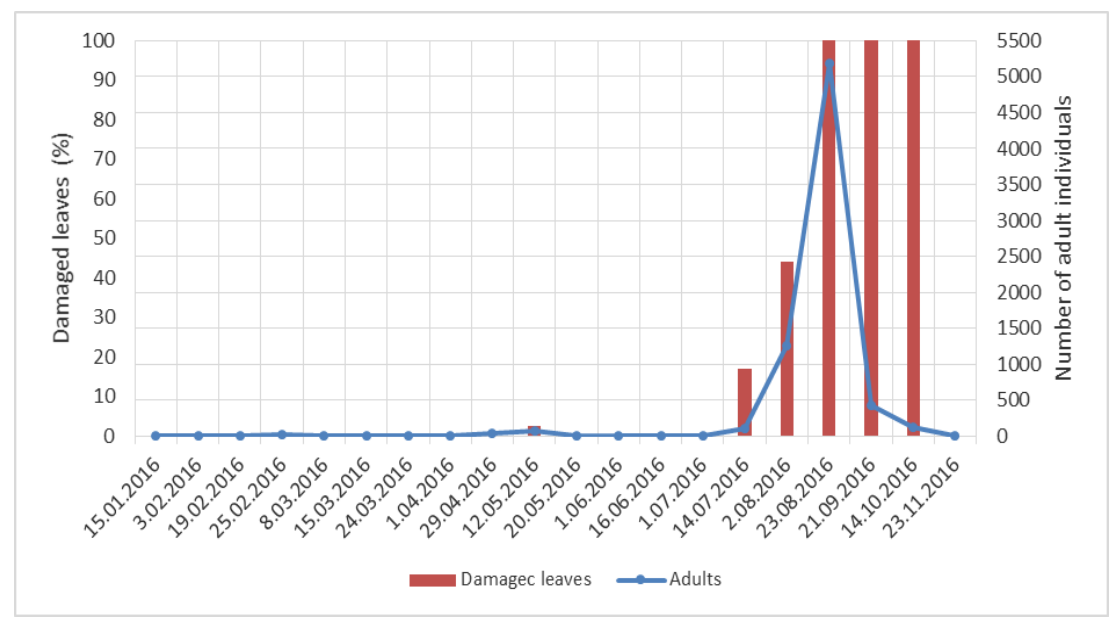

Figure 3. Population fluctuation and damage rates of the Monosteira unicostata (Mulsant \& Rey) in Datça in 2016. 
The first adult individual was found on March 14, 2014 in the Datça district. The adult population reached the highest level on August 14 with 6060 individuals $/ 100$ flapping. The first symptom of damage was determined at $3 \%$ on April 21. A total damage of $100 \%$ was found on 7 August across the Datça (Figure 1).

In 2015, the first adult individuals were found on 26 February. The adult population reached the highest level on August 6 with 6900 individuals/100 flapping. The first symptom of damage was determined at $4.2 \%$ on April 30. A total damage of $100 \%$ was found on 7 July across the Datça (Figure 2).

The first adult individuals of the insect in 2016 were found on February 3 as 7 individuals. The adult population reached the highest level on August 6 with 5187 individuals/100 flapping. The first symptom of damage was determined at $2.5 \%$ on May 12. A total damage of $100 \%$ was found on 23 August across the Datça (Figure 3)

According to the results of the study, the population was lower in 2016 compared to 2014 and 2015 (Figure 3). However, the population of M. unicostata is high for 3 years, especially in July-August, it may be considered an invasive position in Datça district due to the lack of any other insect species other than this pest in almond trees.

In addition, almond production in the Datça region without any insecticide application. Organic almonds are produced in the entire Datça. In this case, the population density of pest is consistently high. Sanchez-Ramos et. al. (2017), also stated that "damages are particularly serious in organic almond orchards".

\section{Discussion}

Brachycaudus amygdalinus (Schouteden), Brachycaudus cardui (Linnaeus), Hyalopterus pruni (Geoffroy), Rhopalosiphum nymphaeae (Linnaeus) species were identified from the Aphididae family and were found to cause damage by feeding the leaves. It was determined that these pests caused the leaves to curl backwards. Although these species were found in all districts, it was determined that there was no dense population of Aphids in Datça district and no damage occurred. Russo et al. (1994), reported $B$. amygdalinus and $M$. unicostata were the most important pest of almonds in southern Italy. Almatni and Khalil (2008), reported that $97 \%$ of the species examined from the almond orchards were $B$. amygdalinus. Alaserhat ve Guclu (2016), recorded $B$. amygdalinus, $B$. cardui, $H$. pruni, $R$. nymphaeae species on almond, pear, quince, walnut, apple, plum, apricot, cranberry, cherry, mahlep, peach and cherry trees in Erzincan and Gümüşhane, Turkey. H. pruni and $B$. amygdalinus were cited on almond and peach trees by Mdellel and Ben Halima (2012). Güncan et al. (2010), stated that B. helichrysi, H. pruni, Myzus persicae and Pterochloroides persicae found in peach orchards in İzmir province.

From the Cicadellidae family, Asymmetrasca decedens (Paoli), Typhlocyba rosae Jensen-Haarup, Zygina discolor (Horvath) species are fed by sucking the leaves and cause the leaves to whitening.

Pentatomidae species Mustha spinosula (Lefèbvre) and Piezodorus lituratus (Fabricius) especially fed on green fresh fruit. Damage to almonds is recognized by gum exuding from puncture sites. Insect feeding can cause black spots on the kernel. Bolu et al. (2006), recorded P. lituratus as most abundant species on almond trees in Diyarbakır, Elazıg, Mardin.

Diaspididae species Lepidosaphes ulmi (Linnaeus) and Parlatoria oleae (Colvee) are damage and become pest status by sucking twigs, shoots and fruit spurs. Many researchers reported that $P$. oleae and $L$. ulmi were found in almond trees (Alkan, 1946; Aysu, 1950; Aysu, 1956; Alkan, 1962; Zümreoğlu, 1972; Yaşar et al.,1995; Karsavuran et al., 2001).

This study was determined for the first time $T$. rosae and $Z$. discolor were fed in almond trees.

\section{Acknowledgements}

The authors are very thankful to Prof. Dr. Hüseyin BAŞPINAR, Doç. Dr. Emine DEMİR ÖZDEN, Dr. Işıl ÖZDEMIR, Dr. Gülten YAZICI, Dr. Cevdet KAPLAN, Dr. Eric GUILBERT for diagnosis of insects and for their helps.

\section{References}

Alaserhat, İ., Güçlü, Ş., 2016. Erzincan ve Gümüşhane illerinde yetiștirilen ılıman iklim meyve türlerinde bulunan Aphididae (Hemiptera) türleri ve doğal düşmanlarının belirlenmesi. Uluslararası Katılımlı Türkiye VI. Bitki Koruma Kongresi (5-8 Eylül 2016, Konya) Bildirileri, 409.

Alkan, B., 1946. Tarım Entomolojisi. Yüksek Ziraat Enstitüsü. Ders kitabı. No:31, Ankara, 232 s.

Alkan, B., 1962. Türkiye'de Ziraat Bitkilerinin Genel Zararlıları Üzerine İncelemeler. Ankara Üniversitesi 
Ziraat Fakültesi Yayınları No:197. Ankara Üniversitesi Basım evi, 32 s.

Aysu, R., 1950. Türkiye koşnilleri 1. Mahsul hekimi, 3(4): 87-91.

Aysu, R., 1956. Parlatoria oleae (Colvée). Tomurcuk, 5(49): 6.

Almatni, W., Khalil, N., 2008. A primary survey of aphid species on almond and peach, and natural enemies of Brachycaudus amygdalinus in As-Sweida, Southern Syria, In: Boos, M. (Ed.), Proceedings Ecofruit-13th International Conference on Cultivation Technique and Phytopathological Problems in Organic Fruit- Growing (Weinsberg, Germany). 109-115.

Bolu, H., Özgen, İ., Fent, M., 2006. Diyarbakır, Elazığ ve Mardin illeri badem ağaçlarında bulunan Pentatomidae (Heteroptera) türleri. Yüzüncü Yıl Üniversitesi Ziraat Fakültesi, Tarım Bilimleri Dergisi,16(1): 25-28.

Babmorad, M., Bagheri Zonouz, E., Yarmand, H., 2004. Lifehistory study of poplar lace bug, Monosteira unicostata (Muls. and Rey) Het.: Tingidae in Karaj. Pajouhesh-Va-Sazandegi, 17(62):71-82.

Gomez-Menor, J., 1950. La chincheta del almendro (Monostira unicostata Mulsant). Bol. Patol. Veg. Entomol. Agric. 17: 97-110.

Güncan, A., Yoldaș, Z., Madanlar, N., 2010. İzmir'de șeftali bahçelerinde bulunan yaprakbiti (Hemiptera: Aphididae) türleri ve doğal düşmanları üzerinde araştırmalar. Türkiye Entomoloji Dergisi 34(3): 399-408."

Karsavuran, Y., Akşit, T., Erkılıç, B.L., 2001. Coccoidea species on fruit trees and ornamentals from Aydin and Izmir provinces of Turkey. Bollettino di Zoologia agraria e di Bachicoltura. Ser. II, 33 (3).

Lodos, N., 1982. Türkiye Entomolojisi II (Genel Uygulamalı ve Faunistik). Ege Üniversitesi Ziraat Fakültesi Yayınları No: 429. Ege Üniversitesi Ziraat Fakültesi Ofset Atölyesi, Bornova, İzmir, 483-490.
Mdellel, L., Ben Halima M.K., 2012. Aphids on almond and peach: Preliminary results about biology in different areas of Tunisia. REDIA. :Vol. XCV, 95:3-8.

Mustafa, S.A., Zubair, S.M., Zandi, Z.A., Al-Maroof, I.N., Kidir, A., Ali, M.A., 2014. Preliminary survey of economic insects and their insect predators in northern Iraq. Munis Entomology Zoology Journal 9(1):150-160.

Maral, H., Ulusoy, M.R., Bolu, M., Guilbert, E., 2013. Diyarbakır, Mardin ve Elazığ illerinde bulunan Tingidae (Hemiptera: Heteroptera) türleri üzerine faunistik çalıșmalar. Türkiye Entomoloji Bülteni 3(4): 139-155.

Önder, F., Karsavuran, Y., Tezcan, S., Meral, F., 2006. Türkiye Heteroptera Kataloğu. Ege Üniversitesi Bitki Koruma Bölümü, Bornova, İzmir. 164 s.

Russo, A., Siscaro, G., Spampinato, R.G., 1994. Almond pests in Sicily. Acta Horticulturae (ISHS), 373:309-316.

Sanchez-Ramos, I., Pascual, S., Fernández, C.E., Marcotegui, A., Gonzalez-Nune, M., 2015. Effect of temperature on the survival and development of the immature stages of Monosteira unicostata (Hemiptera: Tingidae). European Journal of Entomology, 112 (4): 664-675.

Sanchez-Ramos, I., Marcotegui, A., Pascual, S., Fernández, C.E., Guillermo, C., Gonzalez-Nune, M., 2017. Compatibility of organic farming treatments against Monosteira unicostata with non-target arthropod fauna of almond trees canopy. Spanish Journal of Agricultural Research, 15(2), e1004: 110.

Türkiye İstatistik Kurumu. https://biruni.tuik.gov.tr/ medas/ ?kn=92\&locale=tr (son erişim tarihi: 26.06.2018)

Yaşar, B., Özgökçe, S., Kasap, İ., 1995. Van ilinde Coccoidea (Homoptera) üst familyasına bağlı türlerin saptanması üzerine çalışmalar. 1. Diaspididae familyası. Yüzüncü Yıl Üniversitesi Ziraat Fakültesi Dergisi, 5(1): 15-40.

Zümreoğlu, S., 1972. Böcek ve Genel Zararlılar Kataloğu 1928-1969 (1. Kısım). İstiklal Matbaası. İzmir. 119 s. 